Service Encounter Needs Theory: A Dyadic, Psychosocial Approach to Understanding Service Encounters

\author{
Graham L. Bradley, Griffith University \\ Janet R. McColl-Kennedy, The University of Queensland \\ Beverley A. Sparks, Griffith University \\ Nerina L. Jimmieson, The University of Queensland \\ Dieter Zapf, Johann Wolfgang Goethe University
}

\begin{abstract}
Author Note
Graham L. Bradley, School of Psychology, Griffith University, Australia; Janet R. McCollKennedy, UQ Business School, The University of Queensland, Australia; Beverley A. Sparks, Department of Tourism, Leisure, Hotel and Sport Management, Griffith University, Australia; Nerina L. Jimmieson, The University of Queensland, Australia; Dieter Zapf, Johann Wolfgang Goethe University, Germany.

This research was supported by a grant under the Australian Research Council's Discovery Projects funding scheme (project number DP0879469).

Correspondence concerning this chapter should be addressed to Graham L. Bradley, School of Psychology - Gold Coast, Griffith University, Queensland, 4222, Australia. Email: g.bradley@griffith.edu.au
\end{abstract}




\begin{abstract}
Interactions between customers and service providers are ubiquitous. Some of these encounters are routine, but many are characterized by conflict and intense emotions. This chapter introduces a new theory, Service Encounter Needs Theory (SENT), that aims to elucidate the mechanisms through which service encounter behaviors affect outcomes for customers and employees. Evidence is presented for the pre-eminence within these encounters of eight psychosocial needs, and propositions are advanced regarding likely antecedents to fulfilment and violation of these needs. Emotional experiences and displays are viewed as important consequences of need fulfilment and violation, as are numerous cognitive, behavioral, and health-related outcomes.
\end{abstract}




\section{Service Encounter Needs Theory: A Dyadic, Psychosocial Approach to Understanding Service Encounters}

Service industries dominate modern economies. Virtually all people consume services, and about 75\% of workers in developed nations are employed in service industries (Australian Bureau of Statistics, 2008; D’Agostino, Serafini, \& Ward-Warmedinger, 2006). Central to the delivery of most services are the interactions that occur between employees and customers. As in any social interaction, these service encounters have both task and socio-emotional dimensions (Wazlawik, Beavin, \& Jackson, 1969). At a task level, customers expect to receive a desired service at an agreed price, while employees seek to provide the service to standards that at least meet, if not exceed, customer and organizational expectations. In addition to these functional needs, customers and front-line staff have a range of psychosocial needs that must be met for service encounters to be successful.

In this chapter, we propose a theory of Service Encounter Needs (SENT). The centerpiece of this theory is a set of psychosocial needs that is common to both customers and service employees. While past research demonstrates the importance of these needs across multiple domains (Higgins \& Pittman, 2008; Pittman \& Zeigler, 2007), we examine their roles within the specific context of service interactions.

Our perspective resembles the approach of Jahoda (1981) to the meaning of work. Jahoda stated that, while people primarily engage in paid work to earn their living (the manifest function of employment), work also fulfils several latent functions such as the provision of time structure, social contact, collective purpose, social identity/status, and activity (Jahoda, 1981, p.188). Jahoda (1984) argued that people "have deep seated needs for structuring their time use and perspective, for enlarging their social horizon, for participating in collective enterprises where they can feel useful, for knowing they have a recognized place in society, and for being active” (p. 298). Job loss leads to deprivation of both manifest 
and latent functions, but it is primarily the deprivation of the latent functions that causes distress. In a similar vein, service interactions not only fulfil the manifest function of economic transactions in general, namely, satisfying the parties’ material/utilitarian needs, but, we propose, they also have latent functions, namely, meeting the psychosocial needs of employees and customers.

Our theory identifies actions and events that are likely to satisfy or violate these needs, and specifies likely cognitive, affective, behavioral, and health-related outcomes. Underpinning SENT is the notion that motivation, cognition, and emotion are interdependent systems. All three are critical to the management of service interactions. While we acknowledge that the experience, expression and control of emotion are important, and we recognize that emotions can be motivating (they energize and direct behavior), emotions can also be responses to the fulfilment or violation of needs. It is this latter role of emotions that is emphasized within SENT.

\section{Service Encounters, Service Failures and Service Recovery}

Four terms require brief definition. A service provider is a service firm employee who occupies a boundary-spanning role involving contact with customers. A service encounter is an interaction between a customer and a service provider. Service encounters can occur face-to-face or can be mediated by technical devices (e.g., by telephone). A service failure is an instance of service delivery that does not meet a customer's expectations. Service failures can be grouped into core and process failures. Finally, service recovery is an act(s) performed by a service provider that returns the aggrieved customer to a satisfied state (Sparks \& McColl-Kennedy, 2001). Attempts at service recovery vary in effectiveness. Sometimes they make things worse (an outcome known as a “double deviation”), while at other times they give rise to higher levels of customer satisfaction than 
would have been the case without the original service failure (known as the "service recovery paradox”) (De Matos, Henrique, \& Rossi, 2007).

Service encounters are "first and foremost social encounters" (McCallum \& Harrison, 1985, p. 35). They involve processes of dialogue and reciprocal influence between interacting parties (Côté, 2005; Homburg \& Stock, 2005). The focus of our theory is on the mechanism through which behaviors within service encounters affect the parties involved. We argue that the outcomes from service encounters occur in large part because of the impact of the participants' actions on the satisfaction or violation of their own and their service encounter “partner’s” psychosocial needs. All service encounter acts, such as greetings, requests, explanations, apologies, and accusations, can affect psychosocial need fulfilment. Central to SENT is the proposition that the satisfaction or violation of these needs gives rise to a range of emotions (such as annoyance, anger, rage through to contentment, joy and delight). These, in turn, underpin participants' more global evaluations of the service encounter, and, subsequently, their in-role and extra-role behaviors.

\section{The Dyadic Nature of Service Encounters}

All service encounters involve a service provider (employee) and a service receiver (customer, client, patron, patient). As customers, we all occasionally experience poor service, and many of us get into heated exchanges with service firm employees (McCollKennedy, Patterson, Smith, \& Brady 2009). Service workers, meanwhile, may be exposed to conflict-ridden encounters with customers on a daily basis. The potential human and economic costs - in the form of psychological strain, stress-related illness, staff absenteeism and turnover, customer disloyalty and revenge, and lost productivity and profits - is enormous (Dollard, Dormann, Boyd, Winefield, \& Winefield, 2003; Miller, 2003). Perhaps as a consequence, signs such as the following can be seen at many world airports: 
“Assault on Staff. Our aim is to care for passengers ....and we welcome feedback on the customer service we deliver. We must advise that we also care for and aim to protect our staff against verbal and physical abuse.” (Notice, Heathrow airport, London).

Signs such as this demonstrate that service firms are recognizing the potential for adverse outcomes to the parties on both sides of the service desk, and are attempting to address the needs of both parties involved in service interactions.

Scholars have been interested in service work and the dynamics of service encounters for more than twenty years (Czepiel, Solomon, \& Surprenant, 1985; Hochschild, 1983). Over this period, two large but quite separate literatures have emerged. First, there is a body of knowledge in the disciplines of work and organizational psychology, and (human resource) management that relates to service sector workers - their job satisfaction and performance, their job stress, morale and commitment, and their health and wellbeing (e.g., Dollard et al., 2003; Grandey, Dickter, \& Sin, 2004; Zapf, 2002). This literature sheds light on the demands and likely perils of service industry work, but largely ignores the issue of customer satisfaction.

Second, there is a body of knowledge in services marketing that relates to service quality, service encounters/failure/recovery, and customer satisfaction, trust and loyalty (e.g., Davidow, 2003; Parasuraman, Zeithaml, \& Berry, 1985; Smith, Bolton, \& Wagner, 1999). This literature shows that service firm patronage and profitability depend on the quality of service delivery. Indeed, some marketing scholars (e.g., Vargo \& Lusch, 2004) argue that, to prosper, organizations should adopt a "service-dominant logic" - an orientation that emphasizes "customer-centricity” in the delivery of all service(s). Studies within this tradition seldom examine the impact of service encounter behaviors on employee outcomes. 
Consequently, the potential cost to service workers of the single-minded pursuit of service excellence is rarely addressed.

Delivering flawless service is difficult; delivering it consistently over long shifts (and long careers) is probably impossible. Research from the work psychology/management fields (e.g., Demerouti, Bakker, Nachreiner, \& Schaufeli, 2001; Dormann \& Zapf, 2004; Brotheridge \& Grandey, 2002; Grandey et al., 2004; Sprigg \& Jackson, 2006; Zapf, 2002) shows that the effort, empathy, and emotional labor required of workers to deliver excellent service can result in high levels of strain, illness, absenteeism, and eventual turnover. It also shows that doing service can contribute to feelings of personal accomplishment and wellbeing (e.g., Zapf \& Holz, 2006). Service firm profitability thus requires more than providing superior service on a sustained basis to customers. It also requires implementing systems that ensure high levels of employee wellbeing and commitment. These two goals are potentially competing, in that excellent service delivery is often draining on employees, while concern for worker wellbeing may detract from service performance.

Most past research has been undertaken from either the management of employees, or the marketing to customers, perspective. For example, many studies collect satisfaction, loyalty, and similar data from customers only, and draw inferences regarding service quality, service improvement, and, possibly, company strategic direction, from this one-sided perspective (Svensson, 2006). Until recently, few studies - the work on the impact of service climate on employee performance and consequent customer satisfaction (e.g., Schneider, White, \& Paul, 1998) is one major exception - have sought to integrate the two perspectives. Indeed, it is probable that many scholars working in one of the two traditions are largely ignorant of theoretical and empirical advances in the other. Not surprisingly, authors (e.g., Macintosh \& Stevens, 2007) urge researchers to address the issue from both the customer and employee perspectives. 
Rather than focusing on the interests of just one party, SENT adopts a dyadic approach. By identifying needs shared by customers and service employees and responses that are likely to be efficacious for both participants, we seek to balance the potentiallyconflicting interests of these two parties. Our approach to understanding the dynamics of service encounters addresses the question: what are the net (that is, customer plus service provider) outcomes of service encounter actions? Given the complexity of the issues (e.g., Homburg \& Stock, 2005), we also examine contextual and personal factors that moderate the relationships between service encounter actions and outcomes. By defining service encounter success from both parties’ perspectives, our dyadic psychosocial needs approach offers new, practical insights into the effective resolution of common service problems.

\section{Difficult Service Encounters and Stressors}

Due to the nature of services (their intangibility, variability, dependence on customer cooperation, etc) and the interactive nature of service encounters, occasional failures in service delivery are probably inevitable (Sparks, 2001). Encounters that follow or involve a service failure frequently give rise to interpersonal tension and conflict. In contrast to transactions that proceed without mishap, these "difficult” service interactions are likely to generate high levels of felt, even if not always expressed, emotion (c.f. McColl-Kennedy et al., 2009). They are made more complicated by the likely imposition of organizational constraints upon the actions of both parties. Not surprisingly, these encounters have been shown to be a major source of strain for front-line employees (Dormann \& Zapf, 2004; Grandey et al., 2004; Rafaeli, 1989; Weatherly \& Tansik, 1993) and customers (Kalamas, Larcohe, \& Makdessian, 2008; McColl-Kennedy \& Smith, 2006; Yi \& Baumgartner, 2004). Both parties face uncertainty, conflict and the possibility of escalating cycles of anger, rage and abuse (Patterson, McColl-Kennedy, Smith, \& Lu 2009). Both are often required to 
invest considerable time, effort, and other resources in the encounter such that resources may eventually be depleted and a range of stress-related problems ensue (Dollard et al., 2003).

In addition to the stressors encountered by customers in difficult service encounters, employees may experience strain due to at least four kinds of stressors (c.f. Rafaeli, 1989). First, additional workload may be imposed on workers by a service failure. For example, when service is faulty, employees may have to devote considerable time to achieve recovery, they may fall behind in their work, queues may build up, the job may get more hectic, they may be required to work harder, and they may have to skip breaks or work late. Second, the encounter may entail abnormally high levels of complexity. Rather than routinely following scripted roles, service failure situations are often ambiguous and/or unique, and may require service workers to invest additional effort to improvise a solution appropriate to the particular problem. Third, encounters pertaining to service failures potentially involve considerable role conflict, as workers are placed in Bateson’s (1985) three-cornered contest, trying (often in vain) to simultaneously satisfy customer demands for personalized, empathic attention, and organizational expectations of impartiality and efficient "throughput" of customers. Fourth, service encounters typically require participants to engage in emotional labor (Hochschild, 1983; Zapf, 2002). In all service encounters, employees, more so than customers, are expected to regulate their emotional displays, often feigning interest in the customer and engaging in inauthentic displays of positive and/or negative affect. Beyond these requirements of routine service encounters, interactions that involve service failures impose additional emotional loads. The emotional labor involved in displaying culturallyand/or organizationally-appropriate emotions, particularly when these emotions are not genuinely felt (surface acting) and when customers are not constraining the expression of their emotions, can be a major source of employee strain (Dormann \& Zapf, 2004; Brotheridge \& Grandey, 2002; Rupp \& Spencer, 2006; Zapf \& Holz, 2006). 


\section{Behaviors within Difficult Service Encounters}

While SENT may be applied to all service encounters, it particularly focuses on behaviors that occur within difficult and stressful service interactions. The behaviors can be described and categorized in many ways. Distinctions can, for example, be made between spontaneous and scripted service encounter behaviors, authentic and inauthentic behaviors, aggressive, assertive and passive behaviors, and so on. Weiss and Cropanzano (1996) distinguished between "affect-driven” (in the heat of the moment) behaviors and "judgmentdriven” (considered, planned, enduring) behaviors. Van Dolen, de Ruyter, and Lemink (2004) made the additional useful distinction between behaviors that are controlled, produced and performed by a single party to the interaction (what we may call "individualinduced” behaviors), and those that are co-produced through the reactive and reciprocal actions of both parties (“interaction-induced” behaviors).

In our analyses of the dynamics of difficult service encounters, three types of behaviors are of particular interest: (a) service provider actions aimed at service recovery, (b) customer responses to the problem (i.e., service failure) and proposed solution (i.e., recovery attempt), and (c) actions of both participants aimed at self-regulation and the management of service encounter-related stressors.

Service Provider Recovery Attempts. Past research (c.f. Davidow, 2003; Sparks, 2001; McColl-Kennedy \& Sparks 2003; McColl-Kennedy, Daus, \& Sparks, 2003) has identified numerous service provider actions that may be performed to recover from service failure. These include (a) statements acknowledging the harm or loss incurred, (b) responses that reflect empathy or caring, (c) apologies, (d) internal (mea culpa) or external (excuses) explanations for the failure, (e) justifications for the service provider's or firm's actions, (f) attempts to reframe the loss in favorable terms, (g) invitations for, and acceptance of, 
customer input into problem resolution, (h) displays of effort and initiative, (i) commitments to resolve the problem personally and/or immediately, and (j) offers of compensation.

Customer Reactions to Service Failure and Recovery Attempts. Customers are far from passive in service encounters (McColl-Kennedy et al., 2009; Wirtz \& McCollKennedy, 2010). Their behavior influences the dynamics of, and the outcomes from, all service interactions, and also affects the roles played by service providers in such encounters (Rafaeli, 1989; Rupp \& Spencer, 2006; van Dierendonck \& Mevissen, 2002). Some studies (e.g., Dallimore, Sparks, \& Butcher, 2007) have examined customer behavior following service failure and recovery attempts, but few have examined the impact of customer actions on employee behavior and other outcomes. Common customer behaviors can be ordered along a dimension that ranges from those that build mutuality and assist with problem resolution, at one extreme, to those that contribute to escalating "cycles of incivility" (Andersson \& Pearson, 1999; Patterson et al., 2009) and a deepening of the problem, at the other. Specific behaviors of interest include statements that (a) show courtesy vs. rudeness, (b) attribute the cause of the problem to self vs. to the service provider or firm, (c) accept vs. deny responsibility for problem resolution, (d) present legitimate and reasonable vs. unreasonably-high expectations and demands, and (e) express appreciation vs. abuse.

Participant Self-Regulatory Behaviors. Several studies (e.g., Grandey et al., 2004; Harris \& Ogbonna, 2002; Rafaeli, 1989; Reynolds \& Harris, 2006; van Dierendonck \& Mevissen, 2002; Weatherly \& Tansik, 1993) have investigated the strategies used to manage the stressors unique to "difficult” service interactions. Most of this research has examined self-regulation and stress management processes from the perspective of the employee only, although there are some exceptions (e.g., Yi \& Baumgartner, 2004), and many of the insights gained can be applied to the customers involved in the same interactions. In addition to various pre- and post-incident tactics, service provider strategies used during service 
encounters include (a) intra-psychological strategies such as re-appraising, downplaying and ignoring job demands (including demanding customers), (b) problem-focused verbal (“voice”) strategies (i.e., arguing, explaining, negotiating), (c) person-focused verbal strategies (e.g., ingratiating, belittling), (d) eliciting support and assistance from customers and/or colleagues, (e) psychological disengagement strategies (e.g., performing tasks in an automated or mindless manner), and (f) physical escape strategies (e.g., retiring to back-ofhouse, being slow to answer calls).

All service encounter behaviors - all customer responses to service failure, employee-initiated service recovery acts, customer reactions to the recovery attempts, the parties’ stressor- and self-management strategies, and indeed any act that occurs during the ensuing, often heated, interaction - have potential emotional, cognitive, behavioral, health, and economic consequences. The effect may be on the actor him/herself (a so-called “actor effect”) and/or on the other party within the interaction (a "partner-effect”). It may be immediate or delayed, positive or negative. The central premise of SENT is that a limited set of psychosocial needs mediate the various "actor" and "partner" effects of service encounter behaviors on a range of outcomes.

\section{Conceptual Framework}

The conceptual framework underpinning our ideas is provided in Figure 1. From left to right, the model presents (a) a set of factors antecedent to a difficult encounter between a service provider and a customer (boxes 1-4), (b) the encounter itself (box 5), (c) the impact of the encounter on participants' psychosocial needs (box 6), (d) the immediate affective, cognitive, and behavioral responses to need fulfilment or violation (box 7), and (e) the longer-term outcomes of the foregoing processes (boxes 8 and 9). Double-headed straight arrows connecting boxes 3, 4 and 5 indicate that aspects of the failure, the encounter, and the service provider's job mutually influence each other. Solid lines connecting boxes 7 
and 9, and boxes 8 and 10, represent actor effects; dashed lines connecting boxes 7-10 represent partner effects. The double-headed curved arrow connecting boxes 9 and 10 signifies the inter-dependence of customer and employee outcomes.

Insert Figure 1 about here

The framework is over-simplified in several ways. For example, it implies that motivational, cognitive, and affective processes post-date the service encounter when in fact these also occur before, during and after most service interactions. Feedback loops from the immediate and longer-term outcomes to the service encounter and exogenous variables could also be added.

\section{Assumptions Underlying the Theory of Service Encounter Needs}

Many theories contribute to an understanding of service encounter processes and outcomes. Marketing research investigating service interactions has most often been guided by one of three theoretical perspectives: expectancy theory (e.g., Oliver, 1980), equity and justice theories (e.g., Adams, 1965; Bies \& Moag, 1986; Folger \& Cropanzano, 1998; Thibaut \& Walker, 1975), and attribution theory (e.g., Weiner, 1986). These three theoretical approaches identify distinctive variables as likely mediators of the relationships between service delivery and customer evaluations. For example, expectancy theorists focus on instances of confirmation or disconfirmation of expectations; justice theorists refer to the mediating role of perceptions of distributive (outcome), process (formal procedures) and/or interactional (interpersonal treatment) justice; attribution theorists use attributions of locus, stability and controllability to explain these same mediation pathways.

Organizational/work psychologists and management scientists examining the same sorts of processes from the perspective of employees have proposed and tested a plethora of 
theories that seek to shed light on mediation pathways between organizational and work variables, on the one hand, and job strain and involvement, on the other. These theories include generic theories of stress and coping (e.g., cognitive appraisal/ transactional theory (Lazarus \& Folkman, 1984), conservation of resources theory (Hobfoll, 1989)), as well as more specific job-stress theories (e.g., person-environment fit theory (Edwards, Caplan, \& Van Harrison, 2000), demands-control-support theory (Karasek \& Theorell, 1990), job demands-resources theory (Demerouti et al., 2001), effort-reward imbalance theory (Siegrist, 1996), emotional labor theory (e.g., Grandey, 2000), and vitamin theory (Warr, 2007)). Mediation hypotheses derived from these theories most often link job factors to negative employee outcomes by reference to either cognitive appraisals of harm or loss, inequity/injustice perceptions, affective states, self-regulatory attempts, incongruity/inconsistency perceptions, and/or depletion of coping resources (c.f., Elovainio, Kivimaki, \& Helkama, 2004; Weiss, Ashkanasy, \& Beal, 2005).

While evidence exists to support the role of each of these variables, we propose a different explanation. According to SENT, the effects of service encounters on participants can be understood in terms of their impact on participants’ psychosocial needs. Like justice and attribution theories, a strength of the proposed approach is that it can be applied simultaneously to both participants in the interaction, and is thus compatible with the dyadic nature of service encounters. Indeed, we argue that a needs-based approach is of wider applicability than either justice theories (which tend to have greater applicability in situations of injustice, than in situations that are justice-neutral) and attribution theory (which tends to apply better to unusual and unexpected events than to everyday encounters).

The broad assumptions underpinning SENT are similar to those of Murray (1938), Maslow (1943, 1970), and other motivation theorists. These include that behavior is multidetermined, that one category of determinants is a set of inner needs, that humans have 
several such needs, that these needs differ in kind, and that individuals possess and act upon these needs to varying degrees. Based on the work of Murray (1938), Cohen, Stotland, and Wolfe (1955) and others, we define a need as a recurrent concern for a goal state, an inner force that "directs behavior towards a goal and causes tension when the goal is not satisfied" (Cohen et al., p. 291). People are not necessarily aware of the current state of their needs. As Murray (p. 75) notes, the realization of a state of need, "may simply be the experience of a vague 'lack' or ‘pressure’ giving rise to unrest, uneasiness or dissatisfaction.” As opposed to physical needs, satisfaction of psychosocial needs is not necessary for immediate, individual survival, but their satisfaction is important for wellbeing and for psychological thriving (Deci \& Ryan, 2000).

Most of these needs have a biological basis and some evolutionary significance, although they are also substantially shaped by social experience. Deprivation of these needs, or deviation from desired states pertaining to these needs, energizes and directs behaviors aimed at satisfying the need and returning the actor to his or her desired state (Pittman \& Zeigler, 2007). Assumptions underpinning our approach to understanding the role of psychosocial needs within the context of service encounters are listed below.

1. The participants in service encounters not only have material/utilitarian needs. They also have psychosocial needs.

2. Particularly important to service encounter success is a core set of up to eight such needs, namely, the needs for cognition, competence, control, justice, power, trust, respect, and pleasing relations. These needs are shared by customers and employees alike.

3. Individuals differ in the strength of their needs. Need strength tends to be relatively stable over time; it is trait-like. However, the extent to which needs are fulfilled 
varies greatly over time; it is state-like. The focus in SENT is on these differences in need satisfaction, rather than in need strength. (cf. Deci \& Ryan, 2000).

4. Because participants in service encounters reciprocally influence each other, their verbal and non-verbal actions affect the extent to which their own and the other's needs are fulfilled. Because the service encounter is a dynamic process that unfolds over time, need satisfaction varies accordingly. A single service encounter act may affect multiple needs, and a single need may be affected by a range of actions. But not all acts are relevant to all needs (at least, certainly not equally so).

5. It is possible to identify specific verbal and non-verbal service encounter behaviors that are likely to satisfy or violate particular psychosocial needs. Other identifiable acts are likely to satisfy or block multiple needs.

6. Social interactions, in general, and service interactions in particular, do not always go smoothly. All service encounters impinge upon participants’ psychosocial needs, but conflict-ridden, stressful, and otherwise "difficult” interactions pose the greatest threats to these needs.

7. Satisfaction or violation of needs, and the cognitive processing of this occurrence, give rise to a range of affective states. Need satisfaction/violation also leads (perhaps indirectly through affective and cognitive processes) to varying levels of participant satisfaction with the encounter. All these antecedent processes may, in turn, affect participant wellbeing, role-related behaviors (e.g., whether they act as "good customers” or “good employees”), and extra-role behaviors.

8. Knowledge of these contingencies between participant acts and the satisfaction or violation of needs can be used to develop interventions aimed at increasing the extent, frequency, and distribution of customer and employee need fulfilment. 
9. Implementation of such interventions will indirectly (through effects on emotions, cognitions and behavior) lead to enhanced participant satisfaction with, and other desired outcomes from, service encounters.

\section{Bases for Psychosocial Need Selection}

To build the case for the set of psychosocial needs most relevant to service encounters, we drew on five broad sources of ideas and evidence. Our starting point was the classic theories of human motivation proposed in the middle years of the last century. We began with the work of Henry Murray (1938) who distinguished between viscerogenic needs (i.e., biologically-based needs such as those for air, water, food, sex, elimination, and avoidance of danger) and psychogenic needs (i.e., those that rather than having "localizable bodily origins” are concerned with “mental or emotional satisfactions” (p. 77)). Murray maintained that the needs are not necessarily conscious and may give rise to behavior even if the actor is not fully aware of their operation. He proposed more than twenty psychogenic needs organized into several groups, as follows: needs pertaining to social cognition (i.e., needs for cognizance and exposition), needs pertaining to ambition, prestige, and enhancement of the self (e.g., needs for superiority, achievement, recognition); needs pertaining to the defence of status and avoidance of humiliation (e.g., needs for inviolancy, counteraction); needs pertaining to the exercise or acceptance of power (e.g., needs for dominance, deference, autonomy); needs pertaining to affectionate relations with others (e.g., needs for affiliation, nurturance, succorance, play); needs pertaining to sadomasochistic tendencies (i.e., needs for aggression and self-abasement); needs pertaining to inanimate objects (e.g., needs for acquisition, construction, conservation, order); and a need pertaining to obedience and social conformity.

Another early motivation theorist was Abraham Maslow $(1943,1970)$ who, in the best known of his ideas, organized basic human needs and goals into a hierarchy comprising 
five levels (although, as Pittman \& Zeigler (2007) and others have noted, Maslow argued for a more nuanced division of needs than the five-level hierarchy implies). At the bottom level of the hierarchy is physiological needs, followed in ascending order, by needs for safety (e.g. security, stability, protection, freedom from fear), for belonging and love, for esteem (a set of needs that was sub-divided into needs for achievement, mastery and competence on the one hand, and needs for reputation, recognition, prestige, respect and esteem from other people, on the other), and finally, at the apex, the need for self-actualization. Maslow argued that these needs are satisfied in ascending order, such that behavior will not be directed towards satisfying a higher need until all lower needs have been at least reasonably satisfied. Maslow also proposed the existence of motivational tendencies, somewhat independent of his hierarchy, towards obtaining knowledge and understanding, and towards appreciating aesthetic qualities (i.e., beauty, order, symmetry). In sum, seven major kinds of needs were distinguished. Maslow also specified the consequences of satisfaction and violation of the needs. For example, satisfaction of the esteem needs was said to lead to feelings of selfconfidence, worth, strength, and capability, while violation of these needs leads to feelings of inferiority, weakness, and helplessness.

As the second source of ideas and evidence regarding the needs relevant to service encounter interactants, we examined several more contemporary, but still broad, models of motivation and the research that has tested and applied these theories. Perhaps the most influential of the contemporary motivation theories is Deci and Ryan's $(1985,2000)$ SelfDetermination Theory (SDT). This theory proposes the existence of three innate and universal psychological needs, namely, the needs for competence, autonomy, and relatedness. According to Deci and Ryan, all three of these needs must be satisfied for people to develop and function in healthy and optimal ways. The need for competence refers to the need to relate to one's intrapersonal and interpersonal environments in an effective, 
goal-directed manner. The need for autonomy refers to feelings of choice, integration and freedom. The need for relatedness underlies the process of attachment during infancy and extends to the desire for close connections with others throughout life. When the need is threatened, people feel abandoned, lonely and sad.

Fiske (2004) offered a different contemporary conceptualization of motivation. She argued that five fundamental motives have been identified repeatedly by personality and social psychologists over recent decades. The five "core motives in social psychology” are: the need to belong; the need for understanding, for shared meaning and predictability; the need to control, so that people feel competent and effective in dealing with their environment and themselves; the need to enhance the self, to feel special, to feel that one is basically worthy; and the need to trust, to feel good about other people, and to see the social world as a benevolent place. Fiske claimed that the need for belonging underpinned the other four needs. Of the others, the needs for understanding and controlling are relatively cognitive, needs, while the needs to enhance the self and trust the world are more affective. Fiske acknowledged that needs could be deleted or added to her list, citing justice-seeking as one need that could possibly be added.

Our third major source was a range of more circumscribed treatises on aspects of motivation. Foremost amongst these is the work of McClelland, Atkinson, and their colleagues (e.g., Atkinson \& Birch, 1978; McClelland, 1961,1975, 1985). These writers’ major contributions were to the conceptualization, understanding and measurement of three needs: need for achievement (a need to attain and surpass standards of excellence), need for affiliation (a concern for establishing and maintaining positive affectionate relations with other people), and need for power (a concern with controlling and influencing other people). McClelland, Atkinson, and colleagues proposed the existence of stable individual differences in these needs, and identified some of the developmental and contextual correlates of these 
differences. Also included in this third category of influences upon our ideas were the works of White (1959) on effectance motivation, DeCharms (1968) on agency and personal causation, Brehm and Brehm (1991) on reactance, Festinger (1957) on cognitive consistency, Bowlby (1969) and Ainsworth (1989) on attachment, Cacioppo and Petty (1982) on the need for cognition, Baumeister and Leary (1995) on the need to belong, Bandura (1997) on self-efficacy, and Skinner (1996) and Shapiro, Schwartz, and Astin (1996) on the need for control.

Fourth, we drew on recent theoretical and empirical literature that uses a "needs approach” to explain psychosocial events and outcomes. For example, in his needs-threat model of social ostracism, Williams (1997) proposes that ostracism is aversive to the extent that it prevents individuals fulfilling four fundamental, yet inter-dependent, needs, namely, the needs for belongingness (i.e., for frequent positive stable interactions with others), selfesteem (i.e., a need to believe one is a good and worthy person), sense of control (including a need for control over desired outcomes), and meaningful existence. As another example of a needs-based approach to social issues, Van Vugt’s (2009) premised his analysis of environmental protection on the notion that human behavior is shaped by four core motives the needs for understanding (people want information, certainty, predictability), belonging (people want to identify with and form attachments to others), trusting (people want to have confidence in the benevolence of individuals and institutions), and self-enhancement (people want rewards and want to avoid punishment). Van Vugt argued that knowledge of these motives can be used to design effective environmental protection strategies.

Research by Ohbuchi and Tedeschi (1997) also illustrates this approach. These researchers investigated the relationships between participants’ goals and tactical behaviors in social conflict situations. After factor analysis, six goals were identified, with several of these (relationship goals, power-hostility goals, justice goals, identity goals) closely 
resembling the psychosocial needs identified by other writers. As a final illustration of this source of ideas, Shnabel and Nadler (2008) proposed and tested a needs-based model of reconciliation following conflict. The model posits that being a victim represents a threat to one’s status and power, whereas being a perpetrator threatens one’s relatedness, one’s image as moral and socially responsible. Reconciliation thus requires victims to restore their power and perpetrators to restore their public image. Shnabel and Nadler hypothesized and found that actions (e.g., offering an apology and granting forgiveness) that satisfy the different needs of perpetrators and victims (i.e., needs for relatedness/social acceptance and power/status, respectively) promote willingness to reconcile. Thus, the desired outcome (willingness to reconcile) was achieved through actions that met the other party's psychosocial needs.

Finally, we examined the services marketing and management literature for evidence of the roles played by psychosocial needs in the processes of service delivery and service encounter failure and recovery (e.g., Bechwati \& Morrin, 2004; McColl-Kennedy et al., 2009; Parasuraman et al., 1985; Smith et al., 1999). For example, Chung-Herrera (2005) used focus groups to identify four basic needs (needs for security, self-esteem, justice, and trust) that customers report in service encounters. Similarly, Chiu and Lin (2004) identified service quality properties corresponding to each of the seven needs in Maslow's expanded hierarchy of needs. For example, love and belongingness needs were thought to be met by service encounter acts that signal approval and empathy. In addition, Harris and Ogbonna's (2002) research into employee acts of “service sabotage” illustrates the operation of (unmet) needs in service workers. This study showed that the triggers for anti-service acts include workplace violations of employees’ needs for fairness, status, power, and control, with some acts performed "almost as a demonstration against perceived subjugation by both management and customers” (p. 171). 
As can be seen, there is reasonable consensus as to the existence of a finite set of core psychosocial needs. Theoretical works reviewed above enabled us to assess the robustness of these needs, while the applied research provided evidence of the particular relevance of a subset of these needs to service encounters. Together, this literature confirms that the eight selected needs are conceptually clear, that they comprise a non-redundant set, and that they have predictive utility in the service context. Although correlated, the needs are likely to have distinctive service encounter-related antecedents and consequences. Later, we discuss these relationships and we explore possible sources of synergistic and conflicting effects of the various needs. But, first, we define the needs and present a rationale for including each within our framework.

\section{Definitions of and Rationale for the Needs}

In this section, we present arguments for the inclusion within SENT of eight needs pertinent to the parties within service interactions.

First, participants in service encounters have a need for cognition. Customers and employees need to know, understand, and make sense of their circumstances. They want information so that they are able to explain past occurrences, interpret ongoing events, predict future occurrences, and make plans to act accordingly. They want to minimize ambiguity and uncertainty. They do not want to feel ignorant, confused, or bewildered by what is going on in the service encounter. This need for cognition (or something that closely resembles it) is included in the needs identified by Murray (1938), Maslow (1943), Cacioppo and Petty (1982), Fiske (2004), van Vugt (2009) and others. Festinger’s (1957) work on cognitive dissonance/consistency is also relevant. The operation of this need within service encounters is illustrated in our own research (e.g., McColl-Kennedy \& Sparks, 2003) in which customers report strong desires to receive an explanation for service failures. Other 
researchers (e.g., Matilla, 2006) show that explanations given to customers tend to mitigate the ill-effects of service failures.

Second, the encounter must enable the parties to fulfil their need for a sense of their own competence and self-efficacy. They want to feel that they have been able to perform whatever behaviors are required in the particular encounter and that their actions have had the desired effect. They must feel able, useful and efficacious. They do not want to act, feel or look foolish. The need is represented in one component of Maslow's esteem needs, and is given prominence in SDT. It partially overlaps with the need for achievement described by Murray (1938) and McClelland (1961, 1985), and resembles White’s (1959) idea of effectance motivation. Research into negotiation also points to the importance of this need. Rubin (1983), for example, notes that "the key to inducing conciliatory behavior is not coercion and intimidation but a set of moves that encourage the other negotiator to feel competent and effective” (p. 141). Only a few studies (e.g., Chung-Herrera, 2005; Harris \& Ogbonna, 2002; Rafaeli, 1989) have discussed the role of this need in service encounters.

Third is the need to feel in control. The parties in service encounters want to feel that they can influence, manage, and master their environment and the events and outcomes that occur within it. They want a sense of their own agency or internal locus of control, that they are not being controlled by external or random forces. This need for control is readily distinguishable from the need for competence/self-efficacy in that the need for competence relates to the efficacy of one's own behavior, whereas the need for control relates to mastery over one’s circumstances or environment. As Bandura (1997, p. 20) observed, “[b]eliefs about whether one can produce certain actions (perceived self-efficacy) cannot be considered the same as whether actions affect outcomes (locus of control)”. A need for control is recognized as a core motive in the work of Fiske (2004) and Shapiro et al. (1996). DeCharm's (1968) ideas about personal causation and agency, and STD's notion of 
autonomy, are also closely related. Theories of job strain (e.g., Karasek \& Theorell, 1990) also place emphasis on the need for worker control. A large body of research has documented the importance of this need to both customers and workers (c.f., Bateson, 1985; Rafaeli, 1989; Terry \& Jimmieson, 1999; Yagil \& Gal, 2002). Moreover, research (Chang, 2006) has shown that the provision of choice to customers is linked to an enhanced sense of control and hence to customers' affective responses to service.

The fourth is the need for power. This refers to a need to dominate, to be superior, to win a competitive game, to triumph over the other. As defined here, it is distinguishable from the need for control in that it relates specifically to the relative status of the two parties within the service encounter. The power need has a complement in the need for deference (or submissiveness) which, although less common, is evident in some service encounters. The needs for power and deference have a distinctly social connotation; at core, they are concerned with establishing and maintaining a personally (dis)advantageous place within the social hierarchy. Murray (1938) included needs for dominance and deference in his list of psychogenic needs. The need for power has also been described by McClelland (1975). Within the services field, Yagil (2006) has examined the effects of employee power needs, empowerment and burnout on customer satisfaction, while Menon and Bansal (2006) have explored consumer experiences of social power during service consumption. Several authors (e.g., Yagil, 2008) have commented that the employee is at a power disadvantage within most service encounters - it is the customer's, not the employee's, needs that are the primary concern of service organizations - and this means that employees frequently resort to indirect and covert means to satisfy their needs for power (Weatherly \& Tansik, 1993).

Fifth, the parties need to believe that justice has been (or is being) done. The emphasis here is on distributive and procedural justice (rather than on interactional justice). Parties to a service encounter must feel that fair processes have been followed, and just 
outcomes achieved. They must feel that they have given inputs to, and received outputs from, the encounter in equal proportions. Equity (e.g., Adams, 1965) and justice theories (e.g., Folger \& Cropanzano, 1998; Thibaut \& Walker, 1975) provide the most compelling case for the importance of this need. It gains additional support from effort-reward imbalance theory (Siegrist, 1996). Indeed, justice is probably the dominant theoretical framework applied to service recovery (Wirtz \& Mattila, 2004). Many studies have shown links between employee behaviors and customer perceptions of justice, and between customer perceived justice and other service encounter outcomes. For example, Clemmer (1993) argued that fairness/ justice considerations are particularly relevant to service situations, and conducted a survey that identified 16 principles of fairness used by customers. Tax, Brown, and Chandrashekaran (1998) argued on the basis of findings from their survey of complaints that moderately high levels of justice are necessary for customer loyalty and commitment. Liao (2007) tested and supported a model in which service recovery strategies (apologies, courtesy, problem solving and promptness) affect customers’ perceptions of justice, with in turn impact their satisfaction and loyalty. Complementing this research demonstrating the importance of employees treating customers in fair and just ways are other studies (e.g., Bakker, Schaufeli, Sixma, Bosveld, \& van Dierendonck, 2000; Sideman Goldberg \& Grandey, 2007; Rupp \& Spencer, 2006) showing the negative impact of customer-initiated injustices on employee satisfaction, strain and other outcomes. Indeed, Yagil (2008) argues that, in reality, employees seldom fulfil their need to receive something “in return” for the service they provide.

Our sixth need is the need to trust. Service encounter interactants need to feel that they can place trust in the other party's competence and ethical standards. Participants want to feel that the other is reliable, dependable, honest and supportive, and hence that the service provided will be of a high standard and the service received will be appropriately 
recompensed. The need is particularly critical in encounters characterized by high levels of financial or other risk. Fiske (2004) included the need to be trusting as one of her five core psychosocial needs. The importance of this need in service exchanges was argued by Parasuraman et al. (1985), and has since been demonstrated in many studies. For example, Sirdeshmukh, Singh, and Sabol (2002) found that customer loyalty depended on customers having trust in the service organization and the service provider, and Bechwati and Morrin (2004) showed that violations of trust were a common cause of customer rage. Research on emotional labor has emphasized the importance for trusting relations of authentic, rather than fake, emotions (Ashforth \& Humphrey, 1993). In these and most past studies, the emphasis is on customers placing trust in employees, with few researchers taking a dyadic approach in also considering the needs of employees to trust the customer. Recent research into customer misbehavior, or “jaycustomers”, (e.g., Reynolds \& Harris, 2006; Wirtz \& McColl-Kennedy, 2010) makes clear that the trust employees place in customers is frequently violated.

Seventh is the need to be treated with respect. People want to feel that they are valued and held in high regard. They want to be recognized as unique and worthy individuals. They want to be treated with courtesy and dignity in accord with their status. The need to be respected was recognized by Maslow as one of the two components of the need for esteem. Others (e.g., Bies \& Moag, 1986) have written persuasively about the role of interactional justice, a variable that is frequently operationalized in terms of displays of interpersonal respect. The importance of feeling respected by the other party is illustrated in many studies of customers (e.g., Johnston, 1995; Liao, 2007; Sparks \& McColl-Kennedy, 2001; Patterson et al., 2009) and service workers (e.g., Dormann \& Zapf, 2004; Rafaeli, 1989; Rupp \& Spencer, 2006).

Eighth, the parties must feel they have established and maintained pleasing relations with the other. They must feel that their interactions are amicable and pleasant. Ideally, they 
also have some fun. At the least, they must be on good terms with one another when the interaction ends. This need bears some resemblance to Murray’s (1938) needs for affiliation, nurturance and play, Maslow’s love and belongingness needs, McClelland's (1961) need for affiliation, Bowlby's (1969) attachment theory, SDT’s relatedness need, and Fiske's (2004) belonging need, but it is more specific and less deeply-felt than is implied by these other needs. As conceptualized here, it is a need for social synchrony and enjoyment, without the necessity for a deep or prolonged attachment. It is more likely to involve humour and shared joking, than intimacy and the exchange of personal secrets. Evidence of the importance of this need within service interactions comes from studies that demonstrate links between the social aspects of service encounters (rapport, personalization, friendliness, self-disclosure) and customer satisfaction (Gremler \& Gwinner, 2008; Johnston, 1995; Söderlund \& Rosengren, 2008; Worsfold, Worsfold, \& Bradley, 2007). Other studies (e.g., Wegge, Vogt, \& Wecking, 2007) have linked unfriendly customer behavior to increases in service provider strain and decreases in their job performance. Research into emotional contagion in service encounters (e.g., Dallimore et al., 2007; Tombs \& McColl-Kennedy, 2003) shows that positive displays of emotion by one party can be “caught” by the other, leading to a spiral of increasingly positive emotions and enhanced mutual satisfaction with the encounter. Notwithstanding this, there is also evidence (Goodwin \& Smith, 1990) that perceptions of “over-friendliness” impact negatively on customer evaluations.

The need for self-esteem, or enhancement of the self (Baumeister, 1993; Crocker \& Park, 2004), is not included in the set of service encounter needs because we view this as a meta-need. By this we mean that self-esteem is likely to be maintained and enhanced to the extent that the other needs are fulfilled. Thus, service encounter participants will view themselves in positive ways when they understand what is going on, when they have been 
treated fairly, when they regard the other party as benevolent, and when they believe that they are competent, in control, powerful, respected, and well liked.

\section{Propositions Regarding the Relationships Between the Needs}

We now present propositions to be tested in future research. The eight needs within SENT may be roughly ordered along a dimension from, at one pole, those that relate more to task/utilitarian matters (needs for cognition, competence, justice, and control) to, at the other pole, those that have a more exclusively socio-emotional focus (needs for power, respect, trust, and pleasing relations). The former have more to do with agency; the latter are more concerned with relatedness. It is also possible to identify relationships between subsets of needs. For example, satisfaction of the needs for cognition, competence and power may enhance the likelihood that the need for control will also be satisfied (because we tend to feel more in control when we find the world understandable and predictable, when we are performing at our peak, and when we are not threatened by a social competitor (cf. Antonovsky's (1991) sense of coherence). Similarly, satisfaction of the need for respect may be a pre-requisite for satisfying the need for pleasing relations, in that it is difficult to enjoy pleasing relations with another in the absence of displays of politeness and respect.

Conversely, the parties may treat each other respectfully, but still derive little pleasure from the interaction.

Five further propositions regarding the relationships between the needs can now be advanced. The first of these that the importance of satisfying some needs varies between service encounter participants. For example, given that customers more often than employees are in unfamiliar surrounds when engaged in a service interaction, satisfying cognition needs may be more important to customers than to employees. Conversely, competence and control needs may be more important to providers, because these people are performing a job, payment for which requires accuracy and efficiency of service delivery. 
Second, the importance of satisfying the needs varies between types of services. In personal or experiential services, for example, where customer-employee contact is close and prolonged, pleasing relations needs are likely to be particularly critical to service encounter success. In contrast, in non-personal services, where the service may be performed at a time and place remote from the customer, or in credence services, where quality is difficult to evaluate, customers are likely to place priority on fulfilment of trust needs, while employees, expecting little personal contact during performance of the service, may be mainly concerned with fulfilling the more utilitarian needs (e.g., for cognition and competence).

A third proposal is that the importance of satisfying these needs varies between outcomes. For example, while violations of respect and justice needs may be equally predictive of dissatisfaction, justice violations may be more highly predictive of third-party complaining behaviors. The rationale here is that violations of respect (or interactional justice) needs, although keenly felt, may be less objectively demonstrable than are violation of (procedural and distributive) justice needs. Fourth, a distinction can be made between conjunctive and disjunctive service encounter acts. Conjunctive acts work towards the satisfaction of both participants’ needs: a shared joke, for example, may simultaneously contribute to the fulfilment of employee and customer needs for pleasing relations. But service encounters are typically "mixed motive” situations in that the needs and interests of the parties do not perfectly coincide. Thus, some acts may work in a disjunctive manner, that is, by satisfying one's party's needs at the expense of the other's. Power-coercive influence strategies, and tactics that demean the other party, are examples. Finally, additive or interactive combinations of these needs may be necessary to produce particular outcomes. For example, minimal levels of fulfilment of cognitive, justice and respect needs may be 
necessary to ensure the encounter is judged to be satisfactory. Beyond this, any of a number of needs may contribute further to participants’ evaluations.

\section{Propositions Regarding the Antecedents to Need Fulfilment and Violation.}

As already noted, acts and omissions occurring during service encounters can affect the eight psychosocial needs. The act may be verbal (what is said, or not said), vocal (i.e., how it is said - pace, tone, volume), or non-verbal (i.e., actions, rather than words). Some acts (e.g., empathic responses, apologies) may affect several needs. The triggering event may be a single act, or a sequence of acts. It may be performed by the person him/herself (an actor effect), the person with whom she/he is interacting (a partner effect), or a colleague, fellow customer, or supervisor (i.e., a "third party" effect). Often the act is something that causes, exacerbates, or helps resolve a conflict or service failure.

To illustrate, we propose a number of specific service encounter acts and omissions that when performed by one party are likely to have effects on the other's needs. Examples of behaviors that may have such partner effects are given in Table 1 . The proposed needfacilitating and need-hindering effects of these behaviors are derived from a range of literatures. In addition to the theory and research into the service encounter and work stress partially reviewed above, sources include literature in fields of social interaction /communication processes (e.g., Bolton, 1987; Goffman, 1959; Kowalski, 1997) and conflict management (e.g., De Dreu \& Gelfand, 2008; Deutsch, 1973; Koza \& Dant, 2007; Ohbuchi \& Tedsechi, 1997; Pruitt \& Rubin, 1986; Ren \& Gray, 2009). These literatures help pinpoint communication qualities (e.g., reciprocity, mutuality, flexibility) that are likely to satisfy both parties’ needs and hence yield joint-gain (“win-win”) outcomes from service. Drawing on the conflict resolution literature, for example, most entries in the middle column of Table 1 refer to behaviors that are indicative of "integrative” or "cooperative” strategies, whereas the right column reflects "forcing”, "individualistic” and "competitive” approaches. 
Insert Table 1 about here

\section{Propositions Regarding the Consequences of Need Fulfilment and Violation}

There are many potential consequences of the fulfilment or violation of the needs of service encounter participants. For ease of exposition, these consequences are divided into immediate (proximate) and longer-term (remote) outcomes. Importantly, these outcomes relate to both customers and employees. Most of the proximate outcomes are affective and/or cognitive, although "affect-driven” behaviors (Weiss \& Cropanzano, 1996) are also included. Longer-term consequences include “judgment-driven” (more considered, planned, and enduring) behaviors and health-related outcomes.

Whenever needs are engaged, there are affective concomitants. These emotions vary in hedonic tone (pleasant versus unpleasant), intensity (e.g., annoyance versus anger versus rage), and complexity (e.g., fear versus embarrassment). They have physiological correlates including altered patterns of blood flow, respiration, perspiration, muscle tension and gastrointestinal activity. They are expressed in facial expressions, gesture, posture, nonverbal utterances, verbalizations, and reflex behaviors. Their expression may conform to, vary, or violate culturally- or organizationally-prescribed display rules. Thus, service encounter participants may mask (i.e., hide), modulate (i.e., minimize or enhance), or simulate the expression of emotions in response to the satisfaction or thwarting of their needs (c.f. Lord, Klimowski, \& Kanfer, 2002).

Fulfilment of the needs is likely to lead to positive emotions that range from contentment through to happiness and delight, depending on the intensity of the need, prior expectations of need fulfilment, and other personal and contextual factors. Violation of the needs is likely to lead to one or more negatively-toned, basic emotions. Drawing on the 
emotions literature (e.g., Lazarus, 1999; Plutchick, 2001; Weiss \& Cropanzano, 1996) and the application of this literature to service contexts (e.g., McColl-Kennedy \& Smith, 2006; Menon \& Dube, 2004; van Dolen et al., 2004), some propositions can be advanced regarding the likely basic emotional responses to violation of each need. These are illustrated in the middle column of Table 2. As shown, violation of the more task-oriented needs is proposed to be particularly associated with anxiety and shame, whereas violation of relatedness needs is expected to be associated with anger and/or sadness. Violation of different groups of needs is likely to be expressed in non-verbally distinctive ways (McColl-Kennedy et al., 2009). Thus, for example, blocking of cognitive, competence and pleasing relations needs is likely to elicit a more subdued non-verbal response than is violation of justice and respect needs; blood flow (e.g., to the face) may be more apparent following violation of respect needs than following blocking of power needs.

Insert Table 2 about here

In addition to these basic emotions, a more complex set of responses to need fulfilment/violation may be evoked. These responses are shaped by cognitive appraisals and infused with affective qualities, such that they often include a mix of difficult-to-separate cognitive and affective components. Examples of responses to need fulfilment may range from a sense of clarity and certainty (when cognition needs are met) to feelings of mastery (when competency needs are met) and feelings of connectedness (when pleasing relations needs are met). Examples of responses to need violation are given in the far right column of Table 2. As can be seen, a distinctive cognitive-affective outcome results from the violation of each need. Each of these cognitive-affective responses, in turn, is likely to give rise to distinctive behavioral expressions (the body language of, for example, feelings of confusion 
and uncertainty are very different from those associated with feelings of being cheated). Responses also vary in systematic ways between customers and employees, with the latter's behavior more tightly regulated by organizational display rules. Nonetheless, under the accumulated strain of multiple difficult service encounters, the emotional regulation of even the most able employees may be tested. Rupp and Spencer (2006), for example, found that unfair (versus fair) treatment by customers was associated with increased emotional labor on the part of employees and with greater difficulty in complying with display rules.

Over-arching these specific cognitively-mediated responses is the more global cognitive-affective response of satisfaction (Homburg, Koschate, \& Hoyer, 2008). Service encounter participants may be satisfied (or not) with a range of targets, including the other party, the encounter itself, their job (in the case of employees), and the service organization as a whole. We propose that the extent to which the eight needs are met within a service encounter has a strong causal effect on satisfaction with that encounter.

Many of these cognitive-affective outcomes require participants to consider not only their own circumstances but also those of other people, that is, to engage in a process of social comparison. Bandura (1997), for example, observed that a situation in which “[p]eople perceive themselves as ineffectual but see others like them enjoying the benefits of successful effort is likely to give rise to self-disparagement and depression” (p. 21). Similarly, when two customers experience identical service failures but receive different recovery responses, social comparison may lead to anger associated with violation of justice needs (Chung-Herrera, 2005). Other research (c.f. McColl-Kennedy \& Sparks, 2003) suggests that responses are affected by participants' counterfactual thinking, that is, their consideration of what could and should have been, and how they would have felt if things had been different. Thus, while customers might be thinking "how rude! they could have apologized for keeping us waiting”, employees may be muttering “how rude! They should 
have known we are busy, and had the courtesy to wait quietly.” Both parties may thus feel disrespected and devalued.

Behavioral consequences of need satisfaction/violation comprise two broad types: approach and avoidance. Customer approach behaviors include tipping, repatronage and positive word-of-mouth; customer avoidance behaviors include a range of retaliatory responses including negative word-of-mouth behaviors, abuse of service staff, damage to or theft of service firm property, some types of formal complaints, and exiting/firm-switching behaviors (McColl-Kennedy et al., 2009; Wirtz \& McColl-Kennedy, 2010). Employee approach behaviors include greater engagement at work, job commitment, customer orientation and extra-role behaviors; employee avoidance behaviors include cynicism, service sabotage, avoidance of customers, tardiness, absenteeism and other withdrawal behaviors (Davidow, 2003; Sparks, 2001). Importantly, therefore, the extent to which service encounter needs are fulfilled may greatly affect the job performance and job tenure of customer contact staff, with clear financial implications for the employing firm.

Health and wellbeing outcomes are likely to range from states of alertness, energy and vigour, when needs are met and challenging encounters are successfully negotiated, through to states of lethargy, exhaustion or malaise when needs are blocked and conflict escalates or becomes intractable. Repeated experience of need violation may give rise to severe stress and eventually lead to illness outcomes (Spector \& Bruk-Lee, 2008).

For expository purposes, these consequences have been presented in a serial manner, from basic emotions, to more complex affective-cognitive responses, to approach and avoidance behaviors, and finally health-related outcomes. This organization is not intended to imply a linear or unidirectional process. Rather, the outcomes are likely to overlap in time, and are likely to occur in different orders and in different combinations depending on a 
myriad of personal and contextual factors. The unfolding of any set of consequences is dynamic, interactive and highly variable (Côté, 2005).

\section{Propositions to Enhance Service Encounter Outcomes}

The dyadic psychosocial needs approach introduced in this chapter has many potential applications. The aim of all interventions based on SENT is to encourage and enable service encounter behaviors that satisfy the parties’ psychosocial needs. Behaviors that achieve this goal are likely to be characterized by mutuality (vs. self-focus), assertiveness (vs. non-assertion or aggression), bilateral (vs. unilateral) communication, active listening (vs. poor listening or not listening at all), acceptance (vs. denial) of responsibility, collaboration (vs. competition), and joint problem-solving (vs. avoidant and domineering) conflict resolution strategies (Koza \& Dant, 2007). Behaviors of these kinds create the conditions under which integrative interpersonal climates are established, and the possibilities for “win-win” outcomes for customers and employees are maximized (De Dreu \& Gelfand, 2008).

Interventions can be applied at several levels including modification of servicescapes to facilitate participant need fulfilment, educating customers regarding the psychosocial needs of employees, supporting employees threatened by need violation, empowering employees to deliver on customer psychosocial needs, and creating organizational climates that value psychosocial need fulfilment. Most importantly, perhaps, training can focus on educating employees as to the psychosocial needs that operate in service encounters, and specific behaviors that facilitate or hinder need fulfilment. Following Pruitt and Rubin’s (1986) Dual Concern model of conflict management, and consistent with the current dyadic approach, employees can be trained in discourse strategies that involve a high concern for self and a high concern for the customer. Staff may especially benefit from training in actions to be taken when need violation is threatened in themselves or in their customers. By 
learning to decode the early (especially, non-verbal) signs of felt need violation, employees will be well placed to take actions that prevent the escalation of conflict. Training should focus on addressing the needs underlying behavior, rather than just focusing on the customer's (or their own) overt complaint or stated position. As research in conflict management shows, joint gains are most likely to be achieved when both parties have skills in interaction process management, display interpersonal sensitivity, and are willing to disclose their underlying needs (De Dreu \& Gelfand, 2008; Koza \& Dant, 2007). Service employees can be trained through dyadic instruction, case material and role-plays to develop these skills and dispositions.

\section{Proposed Research Directions}

Research opportunities relating to SENT are many. Qualitative studies are required to further elucidate the number and nature of service encounter needs in different cultural settings. Experimental and field research can assess service encounter need fulfilment under varying conditions. Experiments that manipulate participant behaviors and other key variables within simulated service encounters will enable testing of hypotheses regarding the role of psychosocial needs in mediating relationships between service encounter events and outcomes. Diary studies that take repeated measures from customers and employees will enable assessment of within-person variation in events, need fulfilment, emotions, and behaviors. Finally, intervention studies can be conducted to evaluate the impact of programs that train staff to be aware of, and responsive to, service encounter needs.

A number of propositions for testing in future research based on our SENT theory have been presented and include the following:

P1: The importance attached to satisfying each of the eight psychosocial needs (see Table1) varies with (a) the role - customer or provider - played in service encounter, (b) the type of service provided, and (c) the outcome or criterion under consideration. 
P2: Satisfaction or violation of the needs is determined by what happens within service encounters, especially by the behaviors performed by the actor and by the other party. As illustrated in Table 1, specific and identifiable behaviors satisfy different needs.

P3: The eight needs are not satisfied/violated in isolation from each other. Rather, conjunctive, disjunctive, additive, and interactive relationships exist between the needs.

P4: Need satisfaction/violation has affective, cognitive, behavioral, relational, economic, and health-related consequences that vary in observability, duration, and severity.

P5: Both customers and employees can better meet their own and the other party’s service encounters needs by becoming more sensitive to early signs of need violation and more skilled in interaction strategies that facilitate joint need satisfaction.

P6: Planned interventions that focus on these aspects of need fulfilment lead to more satisfied and loyal customers, as well as more satisfied and loyal service employees.

\section{Conclusions}

The contributions of this chapter are four-fold. First, we drew on and integrated a diverse set of literatures. Second, we proposed a new theory, Service Encounter Needs Theory (SENT), and presented evidence from the literature demonstrating its contribution to understanding the mechanisms through which behaviors within service encounters influence the outcomes from these encounters. Third, we put forward for testing in future research several propositions based on the theory regarding the relationships between the needs and regarding the antecedents and consequences of need fulfilment and violation. Fourth, we proposed some ways in which the theory may be applied to enhance service encounter processes and outcomes. 
References

Adams, J. S. (1965). Inequity in social exchange. In L. Berkowitz (Ed.), Advances in experimental social psychology. Vol. 2. (pp. 267-299). New York: Academic Press.

Ainsworth, M. (1989). Attachments beyond infancy. American Psychologist, 44, 709-716. Atkinson, J. W., \& Birch, D. (1978). Introduction to motivation. New York: Van Nostrand. Andersson, L. M., \& Pearson, C. M. (1999). Tit for tat? The spiraling effect of incivility in the workplace. Academy of Management Review, 24, 452-471.

Antonovsky, A. (1991). The structural sources of salutogenetic strengths. In C. L. Cooper \& R. Payne (Eds.), Personality and stress.: Individual differences in the stress process (pp. 67-104). Chichester: Wiley.

Ashforth, B. E., \& Humphrey, R. H. (1993). Emotional labor in service roles: The influence of identity. Academy of Management Review, 18, 88-115.

Australian Bureau of Statistics (2008). Labour statistics in brief. Catalogue 6104.0. Canberra: Australian Government Printing Service.

Bakker, A. B., Schaufeli, W. B., Sixma, H. K., Bosveld, W., \& van Dierendonck, D. (2000). Patient demands, lack of reciprocity, and burnout: A five year longitudinal study among general practitioners. Journal of Organizational Behavior, 21, 425-441.

Bandura, A. (1997). Self-efficacy: The exercise of control. New York: Freeman.

Bateson, J. E. G. (1985). Perceived control and the service encounter. In J.A. Czepiel, M. R. Solomon, \& C. F. Surprenant (Eds.), The service encounter: Managing employee/customer interaction in service businesses (pp. 67-82). Lexington: Lexington Books.

Baumeister, R. F. (Ed.). (1993). Self-esteem: The puzzle of low self-regard. New York: Plnum Press. 
Baumeister, R. F., \& Leary, M. R. (1995). The need to belong: Desire for interpersonal attachments as a fundamental human motivation. Psychological Bulletin, 117, 497529.

Bechwati, N. N., \& Morrin, M. (2004). Outraged customers: What lights their fire? Advances in Consumer Research, 31, 573-574.

Bies, R. J., \& Moag, J. S. (1986). Interaction justice: Communication criteria of fairness. In R. Lewicki, B. Sheppard, \& B. H. Bazerman (Eds.), Research on negotiation in organizations (pp. 43-55). Greenwich, CT: JAI Press.

Bolton, R. (1987). People skills; How to assert yourself, listen to others, and resolve conflicts. Sydney: Simon \& Schuster.

Bowlby, J. (1969). Attachment and Loss: Volume 1: Attachment. London: Hogarth Press.

Brehm, S. S., \& Brehm, J. W. (1991). Psychological reactance: A theory of freedom and control. New York: Academic Press.

Brotheridge, C. M., \& Grandey, A. A. (2002). Emotional labor and burnout: Comparing two perspectives of 'people work'. Journal of Vocational Behavior, 60, 17-39.

Cacioppo, J. T., \& Petty, R. E. (1982). The need for cognition. Journal of Personality and Social Psychology, 42, 116-131.

Chang, C-C. (2006). When service fails: The role of the salesperson and the customer. Psychology and Marketing, 23, 203-224. doi:10.1002/mar.20096

Chiu, H-C., \& Lin, N-P. (2004). A service quality measurement derived from the theory of needs. The Service Industries Journal, 24, 187-204.

Chung-Herrera, B. G. (2005). Customers’ psychological needs in different service industries. Journal of Services Marketing, 21, 263-269. doi: 10.1108/08876040710758568

Clemmer, E. C. (1993). An investigation into the relationship of fairness and customer satisfaction with services. In R. Cropanzano (Ed.), Justice in the workplace: 
Approaching fairness in human resource management (pp. 193-207). Hillsdale, NJ: Erlbaum.

Cohen, A. R., Stotland, E., \& Wolfe, D. M. (1955). An experimental investigation of need for cognition. Journal of Abnormal and Social Psychology, 51, 291-294.

Côté, S. (2005). A social interaction model of the effects of emotion regulation on work strain. Academy of Management Review, 30, 509-530.

Crocker, J. \& Park, L. E. (2004). The costly pursuit of self-esteem. Psychological Bulletin, 130, 392-414.

Czepiel, J. A., Solomon, M. R., \& Suprenant, C.F. (1985). The service encounter: Managing employee/customer interaction in service businesses. Lexington, MA: D. C. Heath and Company.

D’Agostino, A., Serafini, R., \& Ward-Warmedinger, M. E. (2006). Sectoral explanations of employment in Europe - the role of services. European Central Bank - Working Paper Series NO 625 / May 2006.

http://papers.ssrn.com/sol3/papers.cfm?abstract_id=900396

Dallimore, K., Sparks, B. A., \& Butcher, K. (2007). The influence of angry customer outbursts on service providers' facial displays and affective states. Journal of Service Research, 10, 78-92. doi: 10.1177/1094670507304694

Davidow, M. (2003). Organizational responses to customer complaints: What works and what doesn't. Journal of Service Research, 5, 225-250.

DeCharms, R. (1968). Personal causation. New York: Academic Press.

Deci, E. L., \& Ryan, R. M. (1985). Intrinsic motivation and self-determination in human behavior. New York: Plenum.

Deci, E. L., \& Ryan, R. M. (2000). The “what” and “why” of goal pursuits: Human needs and the self-determination of behavior. Psychological Inquiry, 11, 227-268. 
De Dreu, C. K. W., \& Gelfand, M. J. (2008). Conflict in the workplace: Sources, functions, and dynamics across multiple levels of analysis. In C. K. W. De Dreu \& M. J. Gelfand (Eds.), The psychology of conflict and conflict management in organizations (pp. 3-54). New York: Lawrence Erlbaum Associates.

De Matos, C. A., Henrique, J. L., \& Rossi, C. A. V. (2007). Service recovery paradox: A meta-analysis. Journal of Service Research, 10, 60-77. doi:

$10.1177 / 1094670507303012$

Demerouti, E., Bakker, A. B., Nachreiner, F., \& Schaufeli, W. B. (2001). The job demandsresources model of burnout. Journal of Applied Psychology, 86, 499-512.

Deutsch, (1973). The resolution of conflict: Constructive and destructive processes. New Haven, CT: Yale University Press.

Dollard, M. F., Dorman, C., Boyd, C. M., Winefield, H. R., \& Winefield, A. H. (2003). Unique aspects of stress in human service work. Australian Psychologist, 38, 84-91.

Dormann, C., \& Zapf, D. (2004). Customer-related social stressors and burnout. Journal of Occupational Health Psychology, 9, 61-82.

Edwards, J. R., Caplan, R. D., \& Van Harrison, R. (2000). Person-environment fit theory. In C. L. Cooper (Ed.), Theories of organizational stress (pp. 28-67). Oxford: Oxford University Press.

Elovainio, M., Kivimaki, M., \& Helkama, K. (2004). Organizational justice evaluations, job control, and occupational strain. Journal of Applied Psychology, 86, 418-424.

Festinger, L. (1957). A theory of cognitive dissonance. New York: Harper \& Row.

Fiske, S. T. (2004). Social beings: Core motives in social psychology. New York: Wiley.

Folger, R., \& Cropanzano, R. (1998). Organizational justice and human resource management. Thousand Oaks, CA: Sage. 
Goffman, E. (1959). The presentation of self in everyday life. Garden City, New York: Doubleday Anchor.

Goodwin, C., \& Smith, K. L. (1990). Courtesy and friendliness: Conflicting goals for service providers? Journal of Services Marketing, 4, 5-20.

Grandey, A. A. (2000). Emotion regulation in the workplace: A new way to conceptualize emotional labor. Journal of Occupational Health Psychology, 5, 95-110.

Grandey, A. A., Dickter, D. N., \& Sin, H-P. (2004). The customer is not always right: Customer aggression and emotion regulation of service employees. Journal of Organizational Behavior, 25, 397-418. doi: 10.1002/job.252

Gremler, D. D., \& Gwinner, K. P. (2008). Rapport-building behaviors used by retail employees. Journal of Retailing, 84, 308-324. doi:10.1016/j.jretai.2008.07.001

Harris, L. C., \& Ogbonna, E. (2002). Exploring service sabotage: The antecedents, types and consequences of frontline, deviant, antiservice behaviors. Journal of Service Research, 4, 163-183.

Higgins, E. T., \& Pittman, T. S. (2008). Motives of the human animal: Comprehending, managing, and sharing inner states. Annual Review of Psychology, 59, 361-385. doi:10.1146/annurev.psych.59.103006.093726

Hobfoll, S. (1989). Conservation of resources: A new attempt at conceptualizing stress. American Psychologist, 44, 513-524.

Hochschild, A. R. (1983). The managed heart. Los Angeles: University of California Press. Homburg, C., Koschate, N., \& Hoyer, W. D. (2008). The role of cognition and affect in formation of customer satisfaction: A dynamic perspective. Journal of Marketing, 70, 21-31. 
Homburg, C., \& Stock, R. M. (2005). Exploring the conditions under which salesperson work satisfaction can lead to customer satisfaction. Psychology and Marketing, 22, 393-420. doi: 10.1002/mar.20065

Jahoda, M. (1981). Work, employment, and unemployment. Values, theories, and approaches tin social research. American Psychologist, 36, 184-191.

Jahoda, M. (1984). Social institutions and human needs: A comment on Fryer and Payne. Leisure Studies, 3, 297-299.

Johnston, R. (1995). The determinants of service quality: Satisfiers and dissatisfiers. International Journal of Service Industry Management, 6, 53-71.

Kalamas, M., Larcohe, M., \& Makdessian, L. (2008). Reaching the boiling point: Consumers’ negative affective reactions to firm-attributed service failures. Journal of Business Research, 61, 813-824. doi: 10.1016/j.jbusres.207.09.008

Karasek, R., \& Theorell T. (1990). Healthy work: Stress, productivity, and the reconstruction of working life. New York: Basic Books.

Kowalski, R. M. (Ed.). (1997). Aversive interpersonal behaviors. New York: Plenum.

Koza, K. L., \& Dant, R. P. (2007). Effects of relationship climate, control mechanisms, and communications on conflict resolution behavior and performance outcomes. Journal of Retailing, 83, 279-296. doi: 10.1016/j.jretai.2007.03.002

Lazarus, R. S. (1999). Stress and emotion: A new synthesis. London: Free Association.

Lazarus, R. S., \& Folkman, S. (1984). Stress, appraisal and coping. New York: Springer.

Liao, H. (2007). Do it right this time: The role of employee service recovery performance in customer-perceived justice and customer loyalty after service failures. Journal of Applied Psychology, 92, 475-489. doi: 10.1037/0021-9010.92.2.475 
Lord, R. G., Klimowski, R. J., \& Kanfer, R. (Eds.). (2002). Emotions in the workplace. Understanding the structure and role of emotions in organizational behavior. San Francisco: Jossey-Bass.

Macintosh, G., \& Stevens, C. (2007). Personality, motives, and conflict strategies in everyday service encounters. International Journal of Conflict Management, 19, 112131. doi: $10.1108 / 10444060810856067$

Maslow, A. H. (1943). A theory of human motivation. Psychological Review, 50, 370-396.

Maslow, A. H. (1970). Motivation and personality ( ${ }^{\text {rd }}$ ed.). New York: Harper.

Matilla, A. S. (2006). The power of explanations in mitigating the ill-effects of service failures. Journal of Services Marketing, 20, 422-428. doi: $10.1108 / 08876040610704856$

McCallum, R. J., \& Harrison, W. (1985). Interdependence in the service encounter. In J. A. Czepiel, M. R. Solomon, \& C. F. Suprenant (Eds.), The service encounter: Managing employee/customer interaction in services business (pp. 82-113). Lexington: Lexington Books.

McClelland, D. C. (1961). The achieving society. Princeton: Van Nostrand.

McClelland, D. C. (1975). Power: The inner experience. New York: Wiley.

McClelland, D. C. (1985). Human motivation. Glenview, IL: Scott, Foresman.

McColl-Kennedy, J. R., Daus, C., \& Sparks, B. A. (2003). The role of gender in reactions to service failure and recovery. Journal of Service Research, 6, 66-82.

McColl-Kennedy, J. R., Patterson, P. G., Smith, A. K., \& Brady, M. K. (2009). Customer rage episodes: Emotions, expressions and behaviors. Journal of Retailing, 85, 222237.

McColl-Kennedy, J. R., \& Smith, A. K. (2006). Customer emotions in service failure and recovery encounters. In W. J. Zerbe, N. M. Ashkanasy, \& C. E. J. Hartel (Eds.), 
Research on emotions in organization. Volume 2: Individual and organizational perspectives on emotion management and display (pp. 237-268). Elsevier JAI: Amsterdam. doi: 10.1016/S1746-9791(06)02010-4

McColl-Kennedy, J. R., \& Sparks, B. A. (2003). Application of fairness theory to service failures and service recovery. Journal of Service Research, 5, 251-266. doi: $10.1177 / 1094670502238918$

Menon, K., \& Bansal, H. S. (2007). Exploring consumer experience of social power during consumption. International Journal of Service Industry Management, 18, 89-104. doi: 10.1108/09564230710732911

Menon, K., \& Dube, L. (2004). Service provider responses to anxious and angry customers: Different challenges, different payoffs. Journal of Retailing, 80, 229-237. doi: 10.1016/j.jretai.2003.11.002

Miller, P. (2003). The last ten years: Trends in Australian jurisdictions’' stress claims. Australian Psychologist, 38, 81-83.

Murray, H. A. (1938). Explorations in personality. New York: Oxford University Press. Ohbuchi, K-I., \& Tedeschi, J. Y. (1997). Multiple goals and tactical behaviors in social conflicts. Journal of Applied Social Psychology, 27, 2177-2199.

Oliver, R. L. (1980). A cognitive model of the antecedents and consequences of satisfaction decisions. Journal of Marketing Research, 17, 460-469.

Parasuraman, A., Zeithaml, V. A., \& Berry, L. L. (1985). A conceptual model of service quality and its implications for future research. Journal of Marketing, 49, 41-50.

Patterson, P. G., McColl-Kennedy, J. R., Smith, A. K., \& Lu, Z. (2009). Customer rage: Triggers, tipping points and take-outs. California Management Review, 52, 1, 6-28. 
Pittman, T. S., \& Zeigler, K. R. (2007). Basic human needs. In A. W. Kruglanski (Ed.), Social psychology: Handbook of basic principles (2 ${ }^{\text {nd }}$ ed., pp. 473-489). New York: Guilford Publications.

Plutchik, R. (2001). The nature of emotions. American Scientist, 89, 344-356.

Pruitt, D. G., \& Rubin, J. Z. (1986). Social conflict: Escalation, stalemate, and settlement. New York: Random House.

Rafaeli, A. (1989). When cashiers meet customers: An analysis of the role of supermarket cashiers. Academy of Management Journal, 32, 245-273.

Ren, H., \& Gray, B. (2009). Repairing relationship conflict: How violation types and culture influence the effectiveness of restoration rituals. Academy of Management Review, 34, 105-126.

Reynolds, T. J., \& Gutman, J. (1988). Laddering theory, method, analysis, and interpretation. Journal of Advertising Research, 28, 11-31.

Reynolds, K. L., \& Harris, L. C. (2006). Deviant customer behavior: An exploration of frontline employee tactics. Journal of Marketing Theory and Practice, 14, 95-111.

Rubin, J. Z. (1983). Negotiation: An introduction to some issues and themes. American Behavioral Scientist, 27, 135-147.

Rupp, D. E., \& Spencer, S. (2006). When customers lash out: The effects of customer interactional justice on emotional labor and the mediating role of discrete emotions. Journal of Applied Psychology, 91, 971-978. doi: 10.1037/0021-9010.91.4.971

Schneider, B., White, S. S., \& Paul, M. C. (1998). Linking service climate and customer perceptions of service quality: Test of a causal mode. Journal of Applied Psychology, 83, 150-163. 
Shapiro, D. H., Schwartz, C. E., \& Astin, J. A. (1996). Controlling ourselves, controlling our world: Psychology’s role in understanding positive and negative consequences of seeking and gaining control. American Psychologist, 51, 1213-1230.

Shnabel, N., \& Nadler, A. (2008). A needs-based model of reconciliation: Satisfying the differential emotional needs of victims and perpetrators as a key to promoting reconciliation. Journal of Personality and Social Psychology, 94, 116-132. doi: 10.1037/0022-3514.94.1.116

Sideman Goldberg, L., \& Grandey, A. A. (2007). Display rules versus display autonomy: Emotion regulation, emotional exhaustion, and task performance in a call center simulation. Journal of Occupational Health Psychology, 12, 310-318.

Siegrist, J. (1996). Adverse health effects of high-effort/low-reward conditions. Journal of Occupational Health Psychology, 1, 27-41.

Sirdeshmukh, D., Singh, J., \& Sabol, B. (2002). Consumer trust, value, and loyalty in relational exchanges. Journal of Marketing, 66, 15-37.

Skinner, E. A. (1996). A guide to constructs of control. Journal of Personality and Social Psychology, 71, 549-570.

Smith, A., Bolton, R., \& Wagner, J. (1999). A model of customer satisfaction with service encounters involving failure and recovery. Journal of Marketing Research, 36, 356372.

Söderlund, M., \& Rosengren, S. (2008). Revisiting the smiling service worker and customer satisfaction. International Journal of Service Industry Management, 19, 552-574. doi: 10.1108/09564230810903460

Sparks, B. (2001). Managing service failure through recovery. In J. Kandampully, C. Mok, \& B. Sparks (Eds.), Service quality management in hospitality, tourism and leisure (pp. 193-219). New York: Haworth. 
Sparks, B. A., \& McColl-Kennedy, J. R. (2001). Justice options for increased customer satisfaction in a services recovery setting. Journal of Business Research, 54, 209218.

Spector, P. E., \& Bruk-Lee, V. (2008). Conflict, health and wellbeing. In C. K. W. De Dreu \& M. J. Gelfand (Eds.), The psychology of conflict and conflict management in organizations (pp. 267-288). New York: Lawrence Erlbaum Associates.

Sprigg, C. A., \& Jackson. P. R. (2006). Call centers as lean service environments: Jobrelated strain and mediating role of work design. Journal of Occupational Health Psychology, 11, 197-212.

Svensson, G. (2006). New aspects of research into service encounters and service quality. International Journal of Service Industry Management, 17, 245-257. doi: $10.1108 / 09564230610667096$

Tax, S. S., Brown, S. W., \& Chandrashekaran, M. (1998). Customer evaluations of service complaint experiences: Implications for relationship marketing. Journal of Marketing, 62, 60-76.

Terry, D. J., \& Jimmieson, N. L. (1999). Work control and employee wellbeing: A decade review. In C. L. Cooper \& I. T. Robertson (Eds.), International Review of Industrial and Organizational Psychology, Volume 14 (pp. 95-148). Chichester: Wiley.

Thibaut, J., \& Walker, L. (1975). Procedural justice: A psychological analysis. Hillsdale, NJ: Lawrence Erlbaum.

Tombs, A. G., \& McColl-Kennedy, J. R. (2003). The social-servicescape: A conceptual model. Marketing Theory, 3, 447-475. doi: 10.1177/1470593103040785

van Dierendonck, D., \& Mevissen, N. (2002). Aggressive behavior of passengers, conflict management behavior, and burnout among trolley car drivers. International Journal of Stress Management, 9, 345-355. 
van Dolen, W., de Ruyter, K., \& Lemmink, J. (2004). An empirical assessment of the influence of customer emotions and contact employee performance on encounter and relationship satisfaction. Journal of Business Research, 57, 437-444. doi: 10.1016/S0148-2963(02)00277-1

van Vugt, M. (2009). Averting the tragedy of the commons: Using social psychological science to protect the environment. Current Directions in Psychological Science, 18, 169-173. doi: 10.1111/j.1467-8721.2009.01630.x

Vargo, S., \& Lusch, R. F. (2004). Evolving to a new dominant logic for marketing. Journal of Marketing, 68, 1-17.

Warr, P. B. (2007). Work, happiness and unhappiness. Mahwah, NJ: Lawrence Erlbaum.

Wazlawik, P., Beavin, J. H., \& Jackson, D. D. (1969). Human communication - forms, disturbances, paradoxes. Bern: Huber.

Weatherly, K. A., \& Tansik, D. A. (1993). Tactics used by customer-contact workers: Effects of role stress, boundary spanning and control. International Journal of Service Industry Management, 4, 4-17.

Wegge, J., Vogt, J., \& Wecking, C. (2007). Customer induced stress in call centre work: A comparison of audio- and videoconference. Journal of Occupational and Organizational Psychology, 80, 693-712. doi: 10.1348/096317906X164927

Weiner, B. (1986). An attributional theory of motivation and emotion. New York: SpringerVerlag.

Weiss, H. M., Ashkanasy, N. M., \& Beal, D. J. (2005). Attentional and regulatory mechanisms of momentary work motivation and performance. In J. P. Forgas, K. D. Williams, \& S. M. Laham (Eds.), Social motivation: Conscious and unconscious processes (pp. 314-331). Cambridge: Cambridge University Press. 
Weiss, H. M., \& Cropanzano, R. (1996). Affective events theory: A theoretical discussion of the structure, causes, and consequences of affective experiences at work. In B. M. Staw \& L. L. Cummings (Eds.), Research in organizational behavior. Vol. 19. (pp. 174). Greenwich, CT: JAI Press.

White, R. W. (1959). Motivation reconsidered: The concept of competence. Psychological Review, 66, 297-333.

Williams, K. D. (1997). Social ostracism. In R. M. Kowalski (Ed.), Aversive interpersonal behaviors (pp. 133-171). New York: Plenum Press.

Wirtz, J., \& Mattila, A. S. (2004). Consumer responses to compensation, speed of recovery and apology after a service failure. International Journal of Service Industry Management, 15, 150-166.

Wirtz, J., \& McColl-Kennedy, J. R. (2010). Opportunistic customer claiming. Journal of the Academy of Marketing Science. Springer On line 2009. doi: 10.1007/s11747-0090177-6

Worsfold, K., Worsfold, J., \& Bradley, G. L. (2007). Interactive effects of proactive and reactive service recovery strategies: The case of rapport and compensation. Journal of Applied Social Psychology, 37, 2496-2517. doi: 10.1111/j.15591816.2007.00267.x

Yagil, D. (2006). The relationship of service provider power motivation, empowerment and burnout to customer satisfaction. International Journal of Service Industry Management, 17, 258-270. doi: 10.1108/09564230610667104

Yagil, D. (2008). The service providers. Hampshire, UK: Palgrave MacMillan.

Yagil, D., \& Gal, I. (2002). The role of organizational service climate in generating control and empowerment among workers and customers. Journal of Retailing and Consumer Services, 9, 215-226. doi: 10.1016/S0969-6989(01)00033-9 
Yi, S., \& Baumgartner, H. (2004). Coping with negative emotions in purchase-related situations. Journal of Consumer Psychology, 14, 303-317.

Zapf, D. (2002). Emotion work and psychological wellbeing. A review of the literature and some conceptual considerations. Human Resource Management Review, 12, 237-268.

Zapf, D., \& Holz, M. (2006). The positive and negative effects of emotion work in organizations. European Journal of Work and Organizational Psychology, 15, 1-28. 


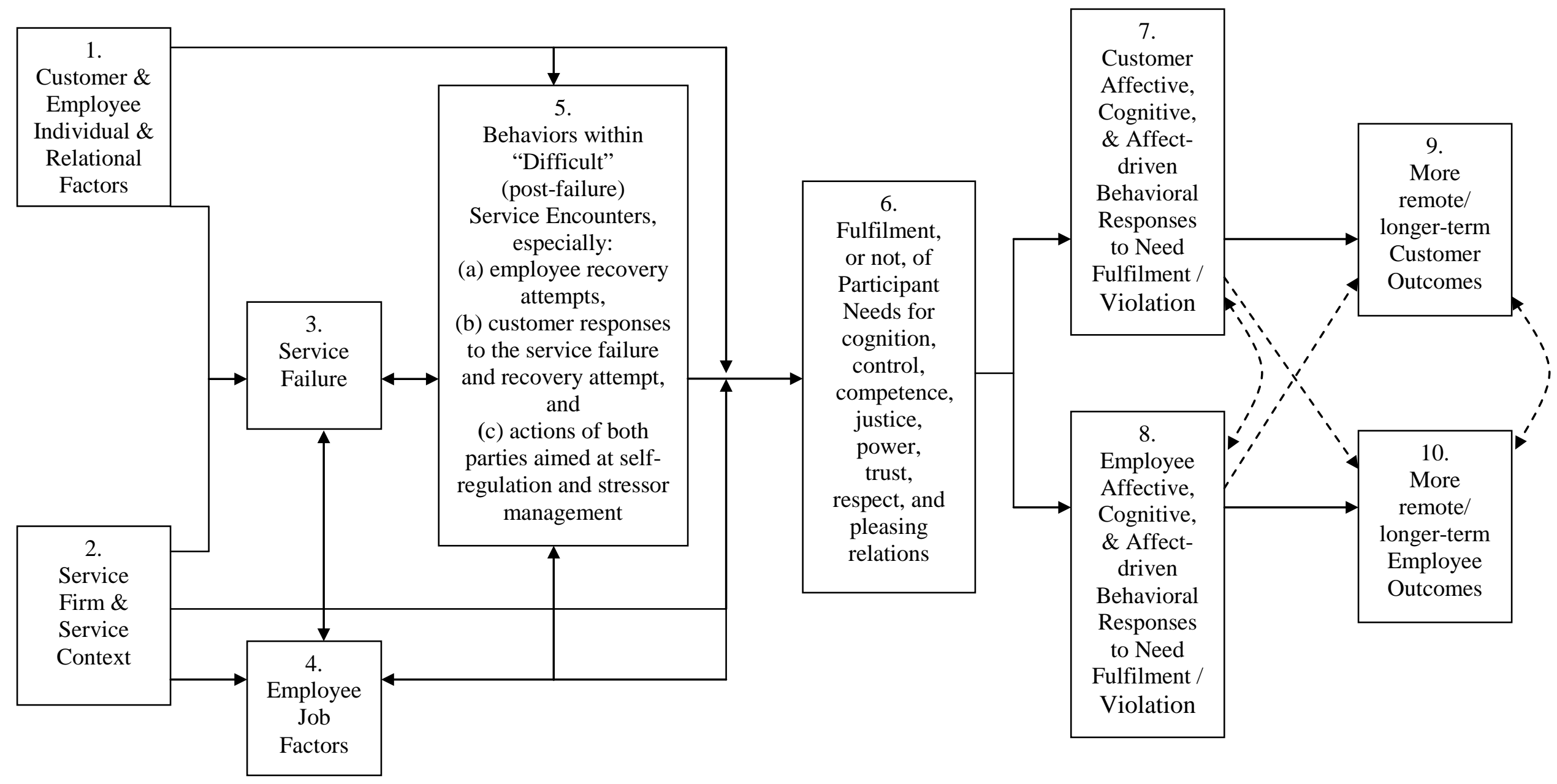

Figure 1. Conceptual framework linking service delivery and outcomes through service encounter needs. 
Table 1.

Proposed Service Encounter Behaviors that Facilitate and Hinder the Eight Psychosocial Needs

\begin{tabular}{|c|c|c|}
\hline Psychosocial Needs pertaining & Examples of Service Encounter Acts & Examples of Service \\
\hline \multirow[t]{2}{*}{ to... } & Proposed to Facilitate Other's Need & Encounter Acts Proposed to \\
\hline & Satisfaction & Hinder Other's Need Satisfaction \\
\hline 1. Cognition & Adherence to standard scripts. & Suppression, filtering and distortion of \\
\hline (understanding, making & Provision of complete, credible, & information. Unexplained deviations from \\
\hline \multirow[t]{2}{*}{ sense, predictability) } & clear explanations, and feedback. & role expectations. \\
\hline & Summarizing statements. & Inarticulate and incomplete statements. \\
\hline 2. Competence & Statements that specify clear and & Use of technical/specialist terms. \\
\hline (self-efficacy, mastery, & manageable expectations. & “Faulting”, i.e., statements that one has done poorly \\
\hline \multirow[t]{5}{*}{ accomplishment) } & Acts that structure the other's tasks in ways & Statements that dismiss one's suggestions and solutions \\
\hline & that facilitate successful performance. & to problem. \\
\hline & Statements by another that exonerate & Inefficient and inaccurate mode of expression that \\
\hline & oneself fromblame, and accept one’s & interferes with role performance. \\
\hline & proposals for action or problem resolution. & Help-rejecting behaviors. \\
\hline 3. Control & Adherence to behavioral scripts. "Voice” & Suppression and filtering of information. \\
\hline (over processes, outcomes, and & procedures. & Restriction of choice. \\
\hline \multirow[t]{2}{*}{ the environment) } & Vertical refenral. & “Stage-hogging”; too much talk; too few questions. \\
\hline & & Over-adherence to policy/rules. \\
\hline 4. Power & Submissive and deferential behaviors and & Coercive social influence strategies, eg giving orders., \\
\hline (dominance over the other & forms of address. & interrupting, belittling, bluffing, threatening, and \\
\hline \multirow[t]{3}{*}{ party) } & Statements that invite the other to voice & intimidating. \\
\hline & opinions, take the lead, lay down ground & Inflexible positional statements. \\
\hline & rules, and in other ways assert themselves. & \\
\hline 5. Justice & Statements reflecting reasonable and & Unrealistically high demands \\
\hline \multirow[t]{3}{*}{ (faimess, equity) } & legitimate expectations. & Unfair/excessive complaints. \\
\hline & Offers of fair compensation. & Unwarranted criticisms. \\
\hline & Giving before trying to take. & Unreciprocated concessions. \\
\hline
\end{tabular}


Honoring the process.

6. Trust

(faith in the other's competence

and benevolence)

7. Respect

(dignity, esteem, status)
Deceitful and cheating behaviors.

Non-verbal indicators of honesty, e.g., eye

Non-verbal indicators of deceit, e.g., avoidance of gaze.

Suppression/distortion of information.

Violation of promises.

Inauthentic displays of emotions.

Deceitful and cheating behaviors.

Rudeness and impoliteness (e.g., in direction of gaze,

use of time, vocal qualities, modes of address).

Impervious or intemupting responses.

Appearing to not listen.

'Hollow' expressions of concern.

Personalising information and solutions.

8. Pleasant Relations (rapport, Appropriately personal forms of address. liking, supportiveness)
Accusations, insults, name-calling, and other instances of hostility, incivility and abuse.

Finding common ground.

Statements of appreciation, compliments. 
Table 2.

Examples of Proposed Affective Consequences of Violation of the Eight Psychosocial Needs

\begin{tabular}{lrr}
\hline Psychosocial Needs & Basic Emotions Evoked by & Cognitive-Affective Response to \\
pertaining to ... & Need Violation $^{\text {a }}$ & Need Violation
\end{tabular}

1. Cognition

anxiety, apprehension

feelings of bewilderment

2. Competence

guilt, shame, embarrassment

feelings of being uselessness

3. Control

anxiety, anger

feelings of helplessness

4. Power

anger, fear, hostility

feelings of impotence

5. Justice

anger, indignation,

feelings of being cheated

envy/guilt

6. Trust

anger, suspicion,

feelings of being betrayed

disappointment

7. Respect

anger, resentment, loathing, feelings of being devalued

contempt

8. Pleasing

sadness, boredom, jealousy

feelings of alienation

Relations

\footnotetext{
${ }^{\mathbf{a}}$ The set of basic emotions was taken from a range of sources including models proposed by Plutchik (2001) and Warr (2007).
} 